\title{
Bridging the Gap: Overtime Gap Time under the Fair Labor Standards Act
}

\section{Hannah Schoeb ${ }^{*}$}

\section{INTRODUCTION}

Imagine a hardworking employee, Ernst. Ernst is hired to complete low skill, hard labor at a slaughterhouse for twelve dollars per hour. $\mathrm{He}$ speaks little English, is not well known to his employer, and is far from indispensable. Each day, Ernst arrives thirty minutes before his assigned shift to set up his work station, works through lunch, and, because the slaughterhouse expects him to complete significant post-shift duties, leaves work thirty minutes after clocking out. The slaughterhouse automatically deducts a full lunch hour from Ernst's recorded hours every day without regard to whether he ate lunch. Because Ernst receives no compensation for the time he spends working through lunch, nor for his pre-shift and post-shift work, the slaughterhouse fails to compensate Ernst for ten work hours per week. ${ }^{1}$ Thus, though Ernst typically works a fortyfive hour week, he only receives compensation for thirty-five hours.

How can Ernst redress this mistake? As a practical matter, he cannot sue his employer in contract, because he cannot afford to anger his employer and risk his livelihood. The United States Department of Labor exists to protect employees from such exploitation, and ordinarily might independently step in to investigate without requiring Ernst to initiate legal action.

\footnotetext{
* Thank you to Kim Flores, Alice Jacks, and all the attorneys at the Kansas City United States Department of Labor, Office of the Solicitor, for allowing me to work with you and learn from you. Thank you Kurt and Mindy Schoeb and Shelby Politte for your unwavering love and support.

1. This hypothetical is adapted from Tyson Foods, Inc. v. Bouaphakeo, 136 S. Ct. 1036 (2016). This Comment assumes pre-shift and post-shift donning and doffing time is compensable as "integral and indispensable" to the employer's principal activities under the Portal-to-Portal Act. Id. at 1039; see 29 U.S.C. § 254 (2012) (Portal-to-Portal Act language addressing "[r]elief from liability and punishment under the Fair Labor Standards Act . . . for failure to pay minimum wage or overtime compensation"); Integrity Staffing Sols., Inc. v. Busk, 135 S. Ct. 513, 519 (2014) ("We hold that an activity is integral and indispensable to the principal activities that an employee is employed to perform - and thus compensable under the FLSA - if it is an intrinsic element of those activities and one with which the employee cannot dispense if he is to perform his principal activities.").
} 
However, as this Comment will explain, under the federal Fair Labor Standards Act of $1938^{2}$ ("FLSA" or "Act") the federal overtime and minimum wage provisions only explicitly require reimbursement for (1) the unpaid hours above the forty-hour per week overtime threshold, and (2) to the extent any unpaid hours cause Ernst's average hourly rate of pay to fall below the statutory minimum wage. ${ }^{3}$ Thus, as to the five hours between Ernst's thirty-fifth and fortieth hour, the FLSA does not facially compel payment ${ }^{4}$ despite the significant financial loss Ernst stands to suffer over time.

These five unpaid hours exemplify what courts have dubbed "overtime gap time." Overtime gap time, the subject of this Comment, involves unpaid non-overtime hours employees work during overtime weeks. Because these hours slip through the statutory gap between the Act's overtime and minimum wage provisions, judges have been largely left to "bridge the gap" as their reasoning compels.

Two distinct common law approaches have emerged. One approach, the "Lundy approach," derives from the Second Circuit's decision in Lundy v. Catholic Health Systems of Long Island Inc., and does not compel overtime gap time reimbursement. The competing approach, the "Monahan approach," 7 derives from the Fourth Circuit's decision in Monahan v. County of Chesterfield and the Ninth Circuit's decision in Donovan v. Crisostomo, ${ }^{8}$ and holds that employees have not been paid proper overtime compensation unless all overtime gap time is also paid.

This Comment argues that the FLSA, its purpose, and proper deference to departmental authority compel courts to recognize a remedy for overtime gap time. Part II outlines the relationship between overtime gap time and the Act, explains the Act's context and purpose, and sets forth the current split in authority among the Courts of Appeals. Part III

2. 29 U.S.C. $§ 201-219$ (2012).

3. Instead, those provisions only explicitly compel reimbursement (1) for any unpaid hours that exceed the forty-hour-per-week overtime threshold, and (2) to the extent an employee's average hourly wage falls below the statutory minimum wage. 29 U.S.C. $\$ 206$ (imposing a minimum wage on all hours worked), 207 (implementing a premium overtime rate of pay as to all hours worked above forty in a single week).

4. Ernst earned twelve dollars per hour, and was paid for thirty-five hours of work. His employer paid him $\$ 420$ total (\$12 per hour x 35 hours paid). Thus, by dividing the hours he actually worked by his total weekly payment, as is necessary to determine whether he is owed any reimbursement under the federal minimum wage provision, Ernst theoretically earned $\$ 9.33$ per hour, a rate that exceeds the minimum wage of $\$ 7.25$ per hour $(\$ 420 / 45$ hours).

5. Monahan v. County of Chesterfield, 95 F.3d 1263, 1266 (4th Cir. 1996).

6. Lundy v. Catholic Health Sys. of Long Island Inc., 711 F.3d 106 (2d Cir. 2013).

7. Monahan, 95 F.3d 1263.

8. Donovan v. Crisostomo, 689 F.2d 869 (9th Cir. 1982). 
advocates for a pro-overtime gap time, "Monahan approach," and rejects the contrary "Lundy approach."

\section{BACKGROUND}

Enacted pursuant to Congress' Commerce Clause authority ${ }^{9}$ to diminish the rampant unemployment and poverty that left America reeling in the wake of the Great Depression, ${ }^{10}$ the FLSA sets forth and implements federal employment standards to combat employers' avarice and ensure individual American workers receive fair pay for humane work. ${ }^{11}$ Today, these employment standards govern private, federal, and state employers whose employees engage in interstate commerce. ${ }^{12}$ Overtime gap time arises under this framework.

Naturally then, this inquiry begins with the Act. This section first outlines the relevant statutory text, regulations, and advisory interpretations and explains how these provisions fail to dictate the appropriate treatment of overtime gap time. It then provides context to help resolve the ambiguity by discussing the history surrounding the FLSA's enactment and the purpose the Congress intended the Act to serve. Finally, it outlines the diverging ways the Courts of Appeals have reconciled the ambiguity and sets forth two distinct approaches to overtime gap time.

\section{A. Overtime Gap Time in Context}

Under the FLSA, federal employment law is simultaneously a statutory and regulatory creature. The FLSA contains broad statutory mandates ${ }^{13}$ and a series of regulations explaining how companies must implement those mandates. ${ }^{14}$ The Wage Hour Division of the Department of Labor ("WHD") implements these provisions and investigates unlawful employment practices under the supervision of an appointed Administrator. ${ }^{15}$ The Act further empowers the Administrator to

\footnotetext{
9. See generally United States v. Darby, 312 U.S. 100 (1941).

10. Lawrence E. Henke, Comment, Is the Fair Labor Standards Act Really Fair? Government Abuse or Financial Necessity: An Analysis of the Fair Labor Standards Act 1974 Amendment-The $\S$ 207(k) Exemption, 52 SMU L. REV. 1847, 1851 (1999).

11. See 29 C.F.R. $§ 776.0$ a (2017).

12. U.S. DEP'T OF LAB., WAGE \& HOUR Division, HANDY REFERENCE Guide tO THE FAIR LABOR STANDARDS ACT 2-3 (2016), https://www.dol.gov/whd/regs/compliance/wh1282.pdf.

13. See 29 U.S.C. $\S \S 201-219$ (2012).

14. See 29 C.F.R. $\$ \S 500-870$ (2017).

15. 29 U.S.C. $\S \S 204,211$.
} 
promulgate regulations that explain, expand, and carry out the broad statutory provisions. ${ }^{16}$ The Administrator routinely issues advisory interpretations, discussed below, to comprehensively explain how this framework operates. ${ }^{17}$

Overtime gap time mainly implicates two sections of the FLSA: the minimum wage provision ${ }^{18}$ and the overtime, or "maximum hours" provision. ${ }^{19}$ Workweeks ${ }^{20}$ in which employees work forty hours or less constitute "nonovertime workweeks." 21 This Comment will refer to workweeks in which employees work more than forty hours as "overtime workweeks." All hours employees work below forty constitute "straight time" hours, ${ }^{22}$ while all hours that employees work beyond forty constitute "overtime hours." 23

The minimum wage provision, codified at 29 U.S.C. $\S 206$, requires that employers pay employees at least a specified minimum wage "rate." 24 The current minimum wage rate is " $\$ 7.25$ an hour." 25 The minimum wage provision does not specify how employers should calculate the wage rate and does not further define the word. ${ }^{26}$ Despite this statutory omission, ${ }^{27}$ parties customarily determine whether an employer has paid at least the minimum wage by comparing the actual remuneration the employee received in a given pay period to the amount the employee would receive if he were paid the minimum wage, computed by multiplying the minimum wage by the number of hours the employee worked. ${ }^{28}$

\footnotetext{
16. Id. $\S \S 204,206-07$; see 29 C.F.R. $\S \S 500-870$.

17. 29 C.F.R. $\S \S 775-794$.

18. 29 U.S.C. $\$ 206$.

19. Id. $\S 207$.

20. A workweek is defined as "seven consecutive 24-hour periods." 29 C.F.R. § 778.105.

21. Id. $\S 778.101$.

22. Though the FLSA does not define "straight time," the regulations issued by the Administrator freely refer to the hours worked below 40 as straight time hours. See, e.g., id. $\S \S$ $778.311,778.315,778.500$.

23. Id. $\S 778.101$.

24. 29 U.S.C. $\$ 206$.

25. Id.

26. See id.

27. The minimum wage provision's failure to describe the appropriate method for determining whether an employer has failed to pay minimum wage is explained in detail in Part III below.

28. See, e.g., 29 C.F.R. § 531.36 (explaining that where an employer deducts amounts for lodging from an employee who receives an hourly rate above the statutory minimum, the deductions will not violate the minimum wage provision and need not follow the rules for making deductions because the employee has received at least the minimum wage for each hour worked); see also Hensley v. MacMillan Bloedel Containers, Inc., 786 F.2d 353, 357 (8th Cir. 1986); Dove v. Coupe, 759 F.2d 167, 172 (D.C. Cir. 1985); Blankenship v. Thurston Motor Lines, Inc., 415 F.2d 1193, 1197-98 (4th Cir. 1969); United States v. Klinghoffer Bros. Realty Corp., 285 F.2d 487, 490 (2d Cir. 1960); 29 C.F.R. $\S 783.43$ (noting that, in the context of computing a seaman's minimum wage, the wage is paid
} 
Critically, because employers need not compensate employees on an hourly basis and instead may structure payments in salary form, the minimum wage provision does not require that employers pay employees for each individual hour an employee works in a week. ${ }^{29}$ Under longstanding practice, so long as the employee's average rate of pay mathematically equals or exceeds the \$7.25-per-hour federal minimum wage for all hours worked, the employer has not violated $\S 206$ - even if the employer omits hours when it calculates compensation so that employees have in fact received zero dollars per hour for some hours of work. ${ }^{30}$

The overtime, or "maximum hours," provision, codified at 29 U.S.C. $\S 207$, forbids any employer from permitting his employees to work more than forty hours in a single workweek, "unless such employee receives compensation for his employment in excess of the hours above specified at a rate not less than one and one-half times the regular rate at which he is employed." 31 The overtime provision purports to define the term "regular rate," but it does not provide an equation for computing the regular rate. ${ }^{32}$ Specifically, in the event that an employer fails to fully compensate its employees for the time they worked, the Act does not indicate whether the regular rate should be computed with reference to each individual hour worked or based on the mathematical average. ${ }^{33}$

Instead, the Act merely states that the regular rate "shall be deemed to include all remuneration for employment paid to, or on behalf of, the employee," and then excludes specific payments that do not resemble typical compensation. ${ }^{34}$ In defining regular rate only by reference to inclusions and exclusions, and without any mathematical formula or further definition, the Act assumes the term is self-explanatory. The regulations and case law provide clarity: they further define the regular rate as the hourly rate at which an employee is employed ${ }^{35}$ during a "normal, non-overtime workweek."

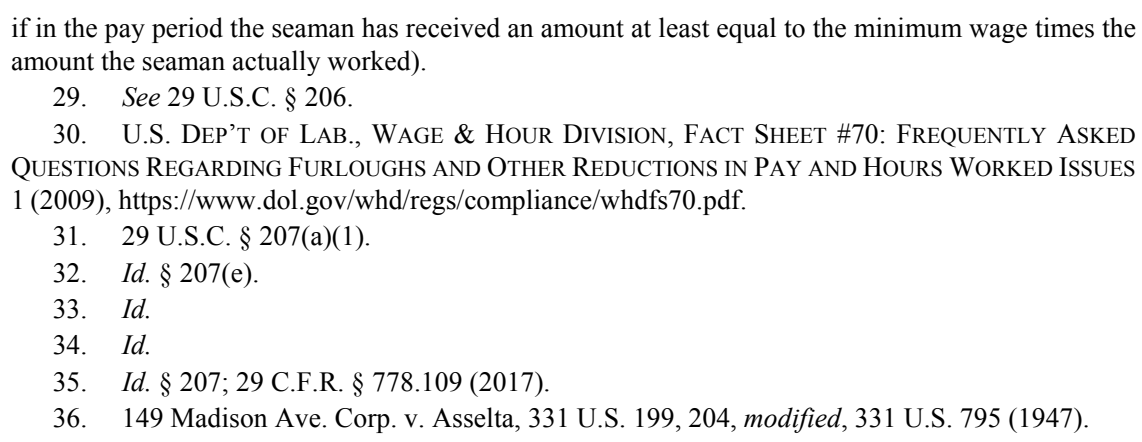


Parties and courts often compute the regular rate "by dividing [an employee's] total remuneration for employment (except statutory exclusions [and overtime compensation already paid] ${ }^{37}$ ) in any workweek by the total number of hours actually worked by him in that workweek." 38 Ordinarily, as to hourly employees, the mathematical regular rate will equal the agreed hourly wage. ${ }^{39}$ Section 207 does not otherwise explicitly discuss payments attributable to the first forty hours an employee works in a week. ${ }^{40}$

If an employer fails to properly compensate his employees pursuant to these provisions, he must pay back wages equal to the amount owed ${ }^{41}$ plus an equal amount for "liquidated damages." liability for liquidated damages if he can prove as an affirmative defense that he acted in good faith. ${ }^{43}$

Though the overtime and minimum wage provisions clearly indicate appropriate pay practices for uncompensated overtime hours and minimum wage violations respectively, no provision clearly governs what courts have dubbed "gap time." 44 "Gap time" refers to uncompensated work time "not covered by the overtime provisions because it does not exceed the overtime limit, and ... not covered by the minimum wage provisions because, even though it is uncompensated, the employees are still being paid a minimum wage when their salaries are averaged across their actual time worked." 45 In nonovertime weeks, this uncompensated straight time is called "pure gap time." "overtime gap time." 47 This Comment analyzes the extent to which the text of sections 206 and 207 support a claim for gap time in Part III below.

The Administrator of the Wage and Hour Division has published several relevant advisory interpretations - codified in the C.F.R. part that

\footnotetext{
37. 29 U.S.C. $\S 207(\mathrm{~h})(2) ; 29$ C.F.R. $\S 778.206$.

38. 29 C.F.R. $\S 778.109$.

39. Id. $\S \S 778.110,778.108$.

40. See 29 U.S.C. $\S 207$.

41. Id. $\S 216(\mathrm{~b})$.

42. Id. $\S \S 216(\mathrm{~b}), 260$.

43. Id. $\S 260$.

44. See Monahan v. County of Chesterfield, 95 F.3d 1263, 1266 (4th Cir. 1996).

45. Rosario v. First Student Mgmt. LLC, No. 15-6478, 2016 WL 4367019, at *4 (E.D. Pa. Aug. 16, 2016) (quoting Adair v. City of Kirkland, 185 F.3d 1055, 1059 (9th Cir. 1999)).

46. See Monahan, 95 F.3d at 1266. In the opening hypothetical, Ernst would have encountered pure gap time if he did not engage in unpaid pre- and post-shift work, such that he actually worked forty (rather than forty-five) hours but was only paid for thirty-five hours. Only one federal circuit has recognized a viable claim for pure gap time. Lamon v. City of Shawnee, 972 F.2d 1145, 1155-58 (10th Cir. 1992).

47. See Monahan, 95 F.3d at 1266 (describing the plaintiffs' overtime gap time claim).
} 
contains the regulations ${ }^{48}$ - that compel employers to pay overtime gap time, but not pure gap time. ${ }^{49}$ However, unlike regulations, these interpretations do not carry the force of law, but instead merely indicate the construction "the Administrator believes to be correct and which will guide him in the performance of his administrative duties under the Act."50 The Act itself does not authorize or even contemplate advisory interpretations, ${ }^{51}$ though it does create the office of the Administrator, and empower the Administrator to enforce the Act through regulations and orders. $^{52}$

Despite their weak statutory authority, the advisory interpretations provide courts with significant guidance, and the Supreme Court has instructed that an interpretation merits deference to the extent a judge finds it persuasive based on "the thoroughness evident in its consideration, the validity of its reasoning, its consistency with earlier and later pronouncements, and all those factors which give it power to persuade." 53 Thus, in ambiguity, judges routinely defer to the Administrator's expertise and accord the interpretations significant weight.

One particularly relevant interpretation, entitled "Payment for all hours worked in overtime workweek is required," provides:

Overtime compensation, at a rate not less than one and one-half times the regular rate of pay, must be paid for each hour worked in the workweek in excess of the applicable maximum hours standard. This extra compensation for the excess hours of overtime work under the Act cannot be said to have been paid to an employee unless all the straight time compensation due him for the nonovertime hours... has been paid. $^{54}$

A related interpretation forbids employers and employees from contracting around this mandate:

An agreement not to compensate employees for certain nonovertime hours stands on no better footing since it would have the same effect of diminishing the employee's total overtime compensation. An agreement, for example, to pay an employee whose maximum hours standard for the particular workweek is 40 hours, $\$ 5$ an hour for the first 35 hours, nothing for the hours between 35 and 40 and $\$ 7.50$ an hour for

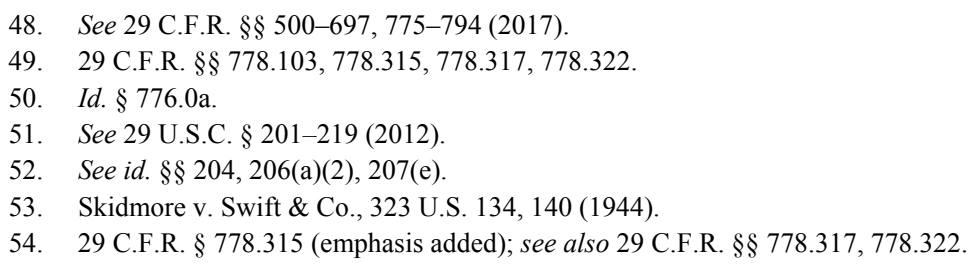


the hours in excess of 40 would not meet the overtime requirements of the Act. Under the principles set forth in $\S 778.315$, the employee would have to be paid $\$ 25$ for the 5 hours worked between 35 and 40 before any sums ostensibly paid for overtime could be credited toward overtime compensation due under the Act. Unless the employee is first paid \$5 for each nonovertime hour worked, the $\$ 7.50$ per hour payment purportedly for overtime hours is not in fact an overtime payment. ${ }^{55}$

Thus, though the text of Act does not explicitly compel payment of gap time, certain advisory interpretations have interpreted the Act to require such payment during overtime weeks, but not during nonovertime weeks. The extent to which these interpretations find textual support is discussed in more detail in Part III below.

Some examples, illustrated in Exhibit 1, clarify the distinction between pure and overtime gap time. Recall Ernst, the slaughterhouse employee who earns $\$ 12$ per hour. Further recall that when Ernst works in the slaughterhouse, he spends thirty unpaid pre-shift minutes preparing his work station and donning protective gear and an equal amount of unpaid time removing, or "doffing," his gear and cleaning his workstation after work, and that he routinely works through lunch without compensation. ${ }^{56}$ Assume that on some days Ernst does not work the slaughterhouse floor, but instead cleans the slaughterhouse, and that on those "cleaning days" he typically eats lunch and does not prepare a work station nor don protective gear. He therefore receives full and accurate compensation on cleaning days.

\section{Exhibit 1.}

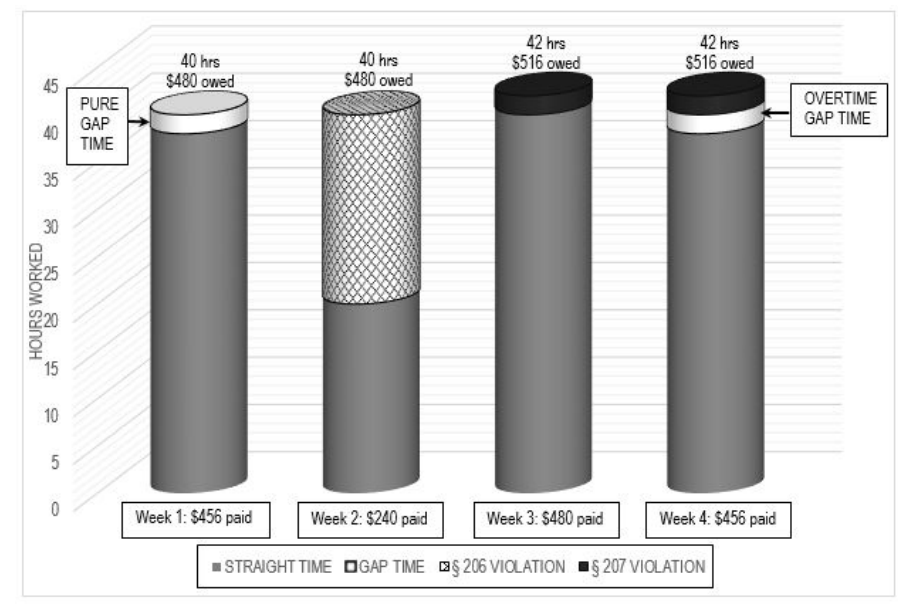

55. $\quad I d . \S 778.317$

56. See, e.g., Tyson Foods v. Bouaphakeo, 136 S. Ct. 1036, 1041 (2016) (finding "donning and doffing" overtime hours compensable under the FLSA). 
In Week 1, the slaughterhouse schedules Ernst to process meat for six hours on Monday, and to clean for eight hours on Tuesday through Friday. Though he is technically only scheduled to work thirty-eight hours during Week 1, because he spends one unpaid hour donning and doffing his protective gear and one unpaid hour working through lunch, he actually works forty compensable hours. Week 1 is a nonovertime workweek because Ernst worked exactly forty hours. The slaughterhouse owes him $\$ 480$ for his work ( $\$ 12 \times 40$ hours), but "shorts" him two straight time hours and pays him $\$ 456(\$ 12 \times 38)$ rather than the $\$ 480$ he is due. Though the slaughterhouse has violated the terms of the parties' express or implied contract, it has not violated the minimum wage provision because Ernst earned $\$ 11.40$ per hour on average $(\$ 456 / 40$ hours $=\$ 11.40)$, an amount that exceeds the $\$ 7.25$ statutory minimum rate of pay. The two straight time hours the slaughterhouse shorts Ernst in Week 1 constitute "pure gap time." They are not compensable under the minimum wage provision.

Assume in Week 2 Ernst cleans every day and works forty hours. Though the slaughterhouse again owes Ernst \$480, it purposely shorts his paycheck by 20 hours and pays him $\$ 240$ for forty hours of work. Mathematically, Ernst earned only $\$ 6.00$ per hour $(\$ 240 / 40$ hours $=\$ 6.00$ per hour), a rate well below the $\$ 7.25$-per-hour statutory minimum wage. As a result, the slaughterhouse violated the minimum wage provision of the FLSA. It must reimburse Ernst the amount necessary to elevate his average rate of pay to $\$ 7.25$ per hour (40 hours $x \$ 7.25$ per hour $=\$ 290$; $\$ 290$ owed $-\$ 240$ paid $=\$ 50$ due). Though Ernst technically earned zero dollars per hour for twenty hours of work, his employer need not pay him the full amount it would owe him for forty hours of work at his regular rate of pay because the minimum wage provision does not require payment for all hours worked.

In Week 3, the slaughterhouse schedules Ernst to process meat for eight hours on Monday and to clean for eight hours Tuesday through Friday. ${ }^{57}$ Because the slaughterhouse owes Ernst compensation for the donning and doffing time and the foregone lunch hour, Ernst works fortytwo, rather than forty, compensable hours in Week 3. The two additional hours make Week 3 an overtime workweek, and the overtime provision now governs. Under the overtime provision, the slaughterhouse owes Ernst \$516 for the work he performed during Week 3, calculated pursuant to his regular rate of pay: $\$ 480$ for hours one through forty (40 hours x $\$ 12$ per hour $=\$ 480)$, and $\$ 36$ for hours forty-one and forty-two $(1.5 \times \$ 12$ "regular rate" $=\$ 18$ per hour; $\$ 18 \times 2$ hours $=\$ 36$ ). If the slaughterhouse

57. Week 3 directly mirrors the facts in Tyson Foods. 
again fails to compensate Ernst for two hours of work and pays him only \$480, it violates the overtime provision and owes Ernst \$36 in back wages.

Confusion arises, however, when the slaughterhouse shorts Ernst both straight and overtime hours during an overtime week. In Week 4, the slaughterhouse schedules Ernst to process meat for six hours on Monday and Tuesday, and clean for eight hours Wednesday through Friday. Ernst is scheduled to work thirty-eight hours in Week 4, but he actually works forty-two compensable hours. Because he worked more than forty hours in Week 4, the overtime provision applies. Ernst's regular rate of pay again entitles him to receive $\$ 516(\$ 12$ per hour $\mathrm{x} 40$ hours $=\$ 480 ; 1.5 \mathrm{x}$ $\$ 12$ per hour $=\$ 18$ per hour overtime rate; $\$ 18 \times 2$ hours $=\$ 36 ; \$ 480+$ $\$ 36=\$ 516$ ). This time, however, the slaughterhouse fails to compensate Ernst for two straight time hours and two overtime hours, and instead pays Ernst \$456. Though the slaughterhouse paid Ernst zero dollars per hour for the shorted hours, it has not indisputably violated the minimum wage provision because Ernst's total compensation divided by the number of hours he actually worked equals an average rate of pay that exceeds the federal minimum wage $(\$ 456 / 42$ hours $=\$ 10.86$ dollars per hour). However, because this is an overtime week, Ernst is entitled to receive compensation at a rate of one and one-half times his regular rate for all hours above forty hours. The slaughterhouse therefore certainly owes Ernst overtime compensation.

Week 4 illustrates the problems that overtime gap time presents. Should the two uncompensated straight time hours "slip through the gap" between the minimum wage and the overtime provisions, so that the slaughterhouse's improper pay practices effectively diminish the full amount it owes? If so, what is the correct overtime rate: one and one-half times Ernst's contractual regular rate of pay, or one and one-half times his mathematical regular rate - the total compensation he received divided by the total hours worked? Has Ernst truly received full and accurate overtime compensation if he receives no pay for the straight time hours? Because the statutory text does not resolve this ambiguity, this Comment next turns to the Act's history and purpose for guidance. ${ }^{58}$

\section{B. Historical Significance and Purpose}

Born amid desperation, the FLSA was enacted to remedy the dire economic hardship that shook the country in the wake of the Great

58. See, e.g., Monahan v. County of Chesterfield, 95 F.3d 1263, 1267 (4th Cir. 1996) (discussing the history and purpose of the Fair Labor Standards Act). 
Depression. ${ }^{59}$ Because this impetus underlies the Act's intent and effect, the Act's history and purpose necessarily informs its interpretation. ${ }^{60}$

In 1929, America veered wildly away from a period of relative economic stability and crashed headlong into a Great Depression. ${ }^{61}$ Over the next ten years, Americans watched as booming stock prices toppled to unmatched lows and the United States' once promising production rates fell from their pedestal, endured four "banking panics," starved through crippling drought and a resulting "dust bowl," and severely curtailed their spending. ${ }^{62}$ Competition for work surged while hiring rates stagnated and fell. ${ }^{63}$ Failing businesses laid off workers in droves, ${ }^{64}$ and millions of Midwesterners abandoned their homes and farms. ${ }^{65}$ By 1933, twenty-five percent of the American workforce and thirty-seven percent of all nonfarm workers were unemployed. ${ }^{66}$ This precarious political climate led to the election of Franklin D. Roosevelt. ${ }^{67}$

Franklin D. Roosevelt was elected president in 1932, ousting incumbent President Herbert Hoover in a landslide victory. ${ }^{68}$ The new president immediately implemented a series of executive orders and comprehensive legislation to address the economic crisis in his famous "New Deal." ${ }^{69}$ The FLSA constituted a key component of Roosevelt's plan to heal the nation. ${ }^{70}$

59. Jonathan Grossman, Fair Labor Standards Act of 1938: Maximum Struggle for a Minimum Wage, U.S. DeP'T OF LABOR OfF. ASSistant Secretary FOR AdMin. \& Mgmt., https://www.dol.gov/oasam/programs/history/flsa1938.htm\#21 (last visited Jan. 28, 2018).

60. See Ruth Milkman, Women Workers and the Fair Labor Standards Act, Past and Present, in A PAPER SERIES COMMEMORATING THE 75TH ANNIVERSARY OF THE FAIR LABOR STANDARDS ACT 281, 284 (2010), https://www.dol.gov/asp/evaluation/reports/FLSAPaperSeries.pdf.

61. See Eric Rouchway, The Great Depression And The New Deal: A Very Short INTRODUCTION 14-19 (2008).

62. See Great Depression, ENCYClOPAEDIA BRITANNICA, https://www.britannica.com/ event/Great-Depression (last visited Jan. 28, 2018).

63. See id.

64. See Rouchway, supra note 61 , at 33 .

65. See id. at $72-87$.

66. Gene Smiley, The Concise Encyclopedia of Economics: Great Depression, LiBR. OF ECON. \& LIBERTY, http://www.econlib.org/library/Enc/GreatDepression.html (last visited Jan. 28, 2018).

67. See Michael E. Parrish, The Great Depression, the New Deal, and the American Legal Order, 59 WASH. L. REV. 723, 723 (1984).

68. RouChWAY, supra note 61 , at 35 .

69. See id. at 56-68.

70. See John S. Forsythe, Legislative History of the Fair Labor Standards Act, 6 L. \& CONTEMP. PRoBs. 464, 472 (1939); see generally Howard D. Samuel, Troubled Passage: The Labor Movement and the Fair Labor Standards Act, MONTHLY LAB. ReV., Dec. 2000, at 32, http://www.bls.gov/opub/mlr/2000/12/art3full.pdf. 
The FLSA was designed to accomplish a primary goal and two competing secondary goals. ${ }^{71}$ Each proffered purpose plainly responds to the economic destitution the Act was intended to ameliorate, and each is plainly carried out through the Act's overtime and minimum wage provisions. ${ }^{72}$ As its overarching purpose, Congress intended the Act to help permanently heal the nation's wounded economy. ${ }^{73}$ The Act accomplishes this economic aim through two competing goals: improve American workers' wages, working conditions, and general well-being, ${ }^{74}$ but balance the benefit it provides to workers against the penalties it imposes on business owners. ${ }^{75}$

The minimum wage provision clearly serves the Act's primary economic goal. ${ }^{76}$ It aims to establish a minimum livable wage sufficient to increase workers' spending power and reduce need for government aid. ${ }^{77}$ Congressional leaders reasoned that the minimum wage would jumpstart economic recovery because workers with more money would demand more products, and industry would respond to this demand by expanding and hiring more employees. ${ }^{78}$

The overtime provision's overarching economic benefit derives from the inherent loss it imposes on employers. ${ }^{79}$ A "cornerstone of the Act," 80 the costly overtime premium rate of pay spreads wealth among the population and combats unemployment. ${ }^{81}$ It does so by providing employers with a choice: ask existing employees to suffer arduous workweeks but pay an accompanying overtime penalty, or "spread the

71. See 29 U.S.C. $§ 202$ (2012); Franklin D. Roosevelt, Fireside Chat (Recovery Program) (July 24, 1933) [hereinafter Roosevelt Fireside Chat] (transcript available at http://www.presidency.ucsb.edu/ws/?pid=14488); see also generally H.R. REP. NO. 1452 (1937).

72. See 29 U.S.C. $\S \S 202,206-07$ (setting forth the statutory purpose and implementing the overtime and minimum wage provisions).

73. See generally Roosevelt Fireside Chat, supra note 71; H.R. REP. No. 1452.

74. See 29 U.S.C. $\S 202$.

75. See id.

76. See Roosevelt Fireside Chat, supra note 71 (discussing the intended effect of minimum wage and maximum hours provisions).

77. 81 CONG. REC. 7713, 7746 (1937) (statement of Sen. Borah).

78. See id. at $7745-47$.

79. See Note, Overtime Compensation Under the Fair Labor Standards Act for Workers with a Fluctuating Number of Hours Per Week, 52 YALE L.J. 159, 160-61 (1942); A "Fireside Chat" Discussing Legislation to Be Recommended to the Extraordinary Session of the Congress, in PUBLIC PAPERS AND ADDRESSES OF FranKLIN D. ROOSEVELT: 1937 VOLUME: THE CONSTITUTION PREVAILS 429, 435 (1937).

80. Defining and Delimiting the Exemptions for Executive, Administrative, Professional, Outside Sales and Computer Employees, 80 Fed. Reg. 38,516, 38,518 (July 6, 2015) (codified at 29 C.F.R. pt. 541) (effective date December 1, 2016).

81. Marc Linder, Moments Are the Elements of Profit: Overtime and the DEREGULATION OF WORKING HOURS UNDER THE FAIR LABOR STANDARDS ACT 35-51 (2000). 
wealth"-hire more workers, reduce each employee's weekly workload, and avoid the overtime penalty. ${ }^{82}$ Thus, the overtime wage largely exists to penalize employers who fail to spread wealth among American citizens. $^{83}$

The Act's second, more targeted goal of diminishing "labor conditions detrimental to the maintenance of the minimum standard of living necessary for health, efficiency, and general well-being of workers," ${ }^{, 4}$ speaks directly to the individual workers who comprise the economy's backbone. ${ }^{85}$ The minimum wage provision facially aids individual workers by ensuring those workers receive a "fair day's pay for a fair day's work." 86 It further purports to prevent an effective "race to the bottom," in which businesses subject workers to increasingly inadequate rates of pay to compete in the marketplace. ${ }^{87}$ Notably, Congress did not design the minimum wage provision to ensure workers live opulent lifestyles, but instead aimed to provide a wage "floor" just sufficient to lift the lowest paid full-time workers out of poverty. ${ }^{88}$

The overtime provision also plainly effectuates the Act's second goal. ${ }^{89}$ Congress designed the overtime penalty to deliver Americans from an unduly "oppressive" workweek, ${ }^{90}$ by simultaneously discouraging overtime and fairly compensating employees for the physical and emotional hardship they suffer during the "intolerable hours" inherent in overtime workweeks. ${ }^{91}$ Roosevelt reasoned that this effective cap on

82. Defining and Delimiting the Exemptions for Executive, Administrative, Professional, Outside Sales and Computer Employees, 80 Fed. Reg. at 38,517.

83. Southland Gasoline Co. v. Bayley, 319 U.S. 44, 48 (1943); Overnight Motor Transp. Co. v. Missel, 316 U.S. 572, 576, 578 (1942), superseded by statute, Portal-to-Portal Act of 1947, Pub. L. No. 80-49, 61 Stat. 84, as recognized in Trans World Airlines, Inc. v. Thurston, 469 U.S. 111 (1985); LINDER, supra note 81 , at 42-43, 47-48.

84. 29 U.S.C. $\S 202(a)(2012)$.

85. See generally United States v. Darby, 312 U.S. 100 (1941).

86. Barrentine v. Ark.-Best Freight Sys., Inc., 450 U.S. 728, 739 (1981).

87. See, e.g., 82 CONG. REC. 1601-02 (1937) (statement of Rep. Martin) (discussing the hardship placed on businesses in states with more progressive employment laws as they struggle to compete with businesses permitted to pay a substandard wage).

88. See 81 ConG. REC. 7745 (1937) (statement of Sen. Black) (arguing that the bill would help those who currently "earn less than a decent living," while remaining limited in scope). See also 82 CONG. REC. 1601 (1937) (statement of Rep. Martin) (acknowledging that the bill is intended to "help the wage earners receive a better break" and "elevate industrial conditions and give protection" from employers who would otherwise pay merely "starvation wages").

89. See LiNDER, supra note 81 , at 41.

90. 82 CONG. REC. 1488 (1937) (statement of Rep. Mott).

91. See LINDER, supra note 81, at 49; Bay Ridge Operating Co. v. Aaron, 334 U.S. 446, 460 (1948). 
permissible weekly working hours would make workers more efficient and happier. ${ }^{92}$

Of course, because the overtime provision does not provide for an absolute cap, employees often work overtime. ${ }^{93}$ Congress reasoned that the increased wage employees receive during overtime workweeks accommodates this problem. ${ }^{94}$ Specifically, the overtime premium fairly compensates employees for the additional physical and emotional suffering they endure when required to work "intolerable hours" during overtime workweeks. ${ }^{95}$

The overtime provision's humanitarian objective and its exemption for certain salaried employees ${ }^{96}$ illuminates the Act's targeted beneficiaries - poor, uneducated, blue collar workers. ${ }^{97}$ Unlike white collar workers - who may freely sit down, take coffee breaks, and leave work periodically - blue collar workers often work in unforgiving conditions. ${ }^{98}$ Congress hoped to improve the health and wellbeing of blue collar workers by minimizing their exposure to the harsh conditions associated with overtime hours. ${ }^{99}$ In this way, the Act shakes its fists at "those who wax rich by paying starvation wages and working women and children long hours," 100 and provides a shield for the nation's working class - those who lack the power to remedy the injustices that plague them. ${ }^{101}$

Finally, in accomplishing these economic and humanitarian aims, the Act aims to balance employers' and employees' competing interests by safeguarding humane employment conditions "without substantially curtailing employment or earning power." 102 The permissive nature of the overtime penalty accommodates this balance. Specifically, Congress favored a financial disincentive over an outright cap because the relatively forgiving economic strain associated with a $50 \%$ overtime wage increase provided employers with more flexibility than an unforgiving ceiling on permitted weekly hours. ${ }^{103}$ The overtime provision's title, “maximum

\footnotetext{
92. See LINDER, supra note 81 , at 49.

93. See id. at $40-42$ (distinguishing a true maximum hours provision from an overtime penalty).

94. See id. at 48-51.

95. See id. at 49; Bay Ridge Operating Co., 334 U.S. at 460.

96. 29 U.S.C. $§ 213(a)(1)(2012)$.

97. See LINDER, supra note 81 , at 9,48 .

98. See id. at 9 .

99. See id.

100. 82 CONG. ReC. 1601 (1937) (statement of Rep. Martin).

101. See H.R. REP. No. 1452, at 56 (1937).

102. 29 U.S.C. $\S 202$ (b) (2012).

103. See LINDER, supra note 81, at 43-44 (discussing Congresspersons' distaste for unforgiving
} 
hours," is instructive in this regard - the penalty is intended to effectuate, without mandating, a forty-hour maximum workweek. ${ }^{104}$

\section{The Circuit Split}

Three Courts of Appeals have implicitly or explicitly considered overtime gap time. Though no clear consensus has emerged, the courts' analyses inform this inquiry.

\section{Donovan v. Crisostomo}

In 1982, the Ninth Circuit considered an issue nearly identical to overtime gap time, used reasoning that illuminates the current overtime gap time inquiry, and set the stage for the cases that would follow. ${ }^{105}$ The case, Donovan v. Crisostomo, involved a construction company that impermissibly required its employees to pay it a cash "kickback" during overtime weeks. ${ }^{106}$ The kickback reduced the employees' regular rate of pay to an amount that differed both from the hourly rate of pay listed on the employees' paychecks and from the hourly rate the employer promised to pay the employees in the parties' employment agreements. ${ }^{107}$ After the district court required the employer to reimburse the employees for the impermissible kickbacks during overtime weeks, the employer appealed, contending that it had not violated the FLSA because the impermissible kickbacks neither related to unpaid overtime hours nor caused the employees' regular rates of pay to fall below the minimum wage. ${ }^{108}$

The Ninth Circuit disagreed. Reasoning that a contrary decision would "frustrate the policy of Section 7 of the FLSA," the court explained that allowing an employer to deduct amounts from straight time pay during overtime workweeks would circumvent the overtime provision's purpose "to spread work and to provide for the strain of long hours by making overtime work more expensive." "109 It further declared that permitting employers to falsely diminish straight time pay during overtime

\footnotetext{
rules and preference for penalties more adaptable to real life work conditions in the context of comparing an outright ban on night work with a heightened rate of pay for night work).

104. LINDER, supra note 81 , at $41,41 \mathrm{n} .181$ (noting that the overtime premium was intended to be "prohibitively costly" (quoting Fighting the War on a 40-Hour Week, N.Y. TIMES, Feb. 16, 1942, at 24)).

105. See generally Donovan v. Crisostomo, 689 F.2d 869 (9th Cir. 1982).

106. Id. at 872 .

107. Id.

108. Id. at 876

109. Id. at $872-76$.
} 
workweeks would provide employers with an opportunity to circumvent "a necessary element of the overtime compensation" and "effectively eliminate the premium paid for overtime by taking kickbacks out of straight time wages in an amount equal to or greater than the overtime premium." 110 Accordingly, the Ninth Circuit concluded that the district court correctly required the employer to reimburse its employees.

\section{Monahan v. County of Chesterfield}

In Monahan v. County of Chesterfield, the Fourth Circuit implicitly recognized an overtime gap time claim. ${ }^{111}$ There, twelve police officers sought compensation for unpaid straight time hours during both nonovertime and overtime weeks. ${ }^{112}$ The County paid the officers pursuant to an extended twenty-four-day pay period with an accompanying 147-hour overtime threshold ${ }^{13}$ (as is authorized by the $\S$ 207(k) exemption). ${ }^{114}$ The officers typically worked 135 hours during their twenty-four-day work cycle, but occasionally instead worked 144 hours during the twenty-four-day cycle. ${ }^{115}$ The County compensated the officers via a biweekly salary, and paid additional compensation at a rate of one and one-half times the officers' regular rate of pay if the employees worked more than 147 hours during the pay period. ${ }^{116}$ The officers always received overtime compensation when they worked more than 147 hours during the pay cycle. ${ }^{117}$

The officers conceded that the County paid an appropriate overtime rate during cycles in which the officers worked more than 147 hours. ${ }^{118}$ They instead alleged that the County only intended their salary to compensate them for 135 hours of work during each cycle, and that it

\footnotetext{
110. Id. at 876.

111. See generally Monahan v. County of Chesterfield, 95 F.3d 1263 (4th Cir. 1996).

112. Id. at $1264-65$.

113. Id. at 1265 .

114. 29 U.S.C. $\S 207(\mathrm{k})(2012)$. Section 207 provides a special exception to the typical fortyhour workweek that permits law enforcement employers to impose an extended work cycle in lieu of a seven-day work cycle, with an accompanying extended overtime threshold in lieu of the forty-hour threshold. See 29 U.S.C. $\S 207 ; 29$ C.F.R. § 553.230 (2017). The regulation permits work cycles as long as twenty-eight days, with an accompanying 171-hour overtime threshold for the twenty-eight day period. $I d$. at $\S 553.230$ (b). Such employers may opt to implement shorter work periods, so long as they compensate employees pursuant to an overtime rate "which bears the same relationship to 171 as the number of days in the work period bears to 28." Id. Thus, for example, for a twenty-four-day work period, the overtime threshold is 147 hours. Id. §553.230(c).

115. Monahan, 95 F.3d at $1265-66$.

116. Id. at 1266 .

117. Id.

118. Id. at 1265 .
} 
shorted them straight time pay when it failed to increase their biweekly paychecks to account for the hours the officers worked between 135 and 147 hours in any work cycle. ${ }^{119}$ Thus, the employees argued, the employer owed them back "overtime gap time" for those uncompensated straight time hours during overtime cycles, and "pure gap time"120 for uncompensated straight time during nonovertime cycles. ${ }^{121}$

The Fourth Circuit ultimately decided in favor of the employer. ${ }^{122}$ However, the court did not disclaim the possibility of a valid overtime gap time claim. ${ }^{123}$ Instead, after construing the FLSA's purpose and intended effect, ${ }^{124}$ deferring to administrative interpretation $\S 778.315,{ }^{125}$ and citing Donovan, ${ }^{126}$ the court predicated its decision on a factual finding that the parties actually intended the biweekly salary to compensate the employees for all straight time hours, including the allegedly unpaid overtime gap time hours. ${ }^{127}$ As a result, the court reasoned, the employer necessarily could not conceivably owe the employees an additional sum for what the court deemed properly compensated straight time hours. ${ }^{128}$

In so holding, the court implicitly recognized that the FLSA provides a remedy for overtime gap time under appropriate circumstances. ${ }^{129}$ The opinion supports this conclusion for two reasons: (1) the court recognized that a party could bring an overtime gap cause of action under appropriate circumstances; and (2) though it could have dispensed with the police officer's pure and overtime gap time claims in one broad stroke, it separately analyzed the issues and dismissed the overtime gap time claim because it found insufficient factual, rather than legal, support. ${ }^{130}$

The Fourth Circuit recognized an overtime gap time claim because it explicitly referred to overtime gap time causes of action and used language that assumes the validity of such claims. ${ }^{131}$ The court recognized such

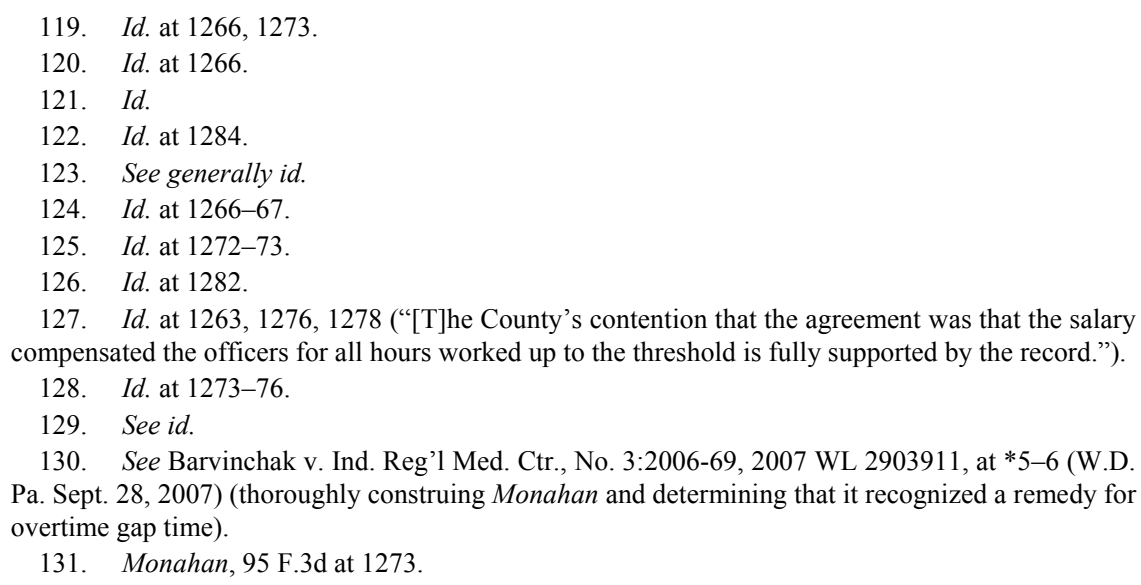


causes of action by setting two conditions precedent to pleading valid overtime gap time claims. First, it stated, "[f]or there to be an overtime gap time cause of action under the FLSA, a violation of section 206 or 207 of the Act must first exist." "132 Next, explaining that courts must consider parties' employment agreements in determining proper overtime compensation, ${ }^{133}$ it articulated a test that sets forth circumstances in which $\S 778.315$ would not support an overtime gap time claim:

$[U]$ nder 778.315 , if (1) all straight time compensation due to the employee for nonovertime hours under the express or implied employment agreement or applicable statute has been paid and (2) the employee has been compensated at a rate of at least time and a half for all hours worked in excess of the maximum allowed, the employer has acted in compliance with the FLSA. ${ }^{134}$

This two-pronged, conjunctive test certainly supports the proposition that FLSA provides a remedy for uncompensated overtime gap time. If the court merely intended to delineate proper pay practices for overtime hours under the FLSA without implicating straight time hours worked during overtime weeks, it need not have required that the employer compensate its employees for all hours worked under the employment agreement - the second part of the rule alone would have sufficed. In fact, although the word "gap" does not appear in the first portion of this quoted language, the language nonetheless implicitly recognizes overtime gap time because no claim for overtime gap time can exist if all straight time compensation during an overtime workweek has been paid - in such circumstances, there is simply no "gap" for the court to fill. Of course, if the court did not recognize overtime gap time, it need not have set forth conditions precedent to validly bringing such claims.

The Fourth Circuit also construed the relevant advisory interpretations in a manner that suggests it recognizes overtime gap time in appropriate circumstances. ${ }^{135}$ It noted that the advisory interpretations that require employers to compensate employees for all straight time hours worked during overtime workweeks "command[] considerable deference" and "constitute a body of experience and informed judgment to which courts and litigants may properly resort for guidance."136 It need not have

132. Id. at 1284 (emphasis added).

133. Id. at 1273 .

134. Id. (emphasis added).

135. See id.

136. Id. at 1272 n. 10 . 
construed and deferred to these advisory interpretations if it found them poorly reasoned or inapplicable.

Next, though a factual inquiry could have dispensed with the overtime and pure gap time claims in one broad stroke, the court instead analyzed the pure and overtime gap time claims separately. ${ }^{137}$ It employed a factbased analysis to dismiss the overtime gap time claim and a distinct legal analysis to dispense with the pure gap time claim. ${ }^{138}$ In distinguishing between the legal and factual disposition, it purported to "place some common sense limitations on claims for straight time brought pursuant to the FLSA." 139

Though the facts of the case did not require it to do so, ${ }^{140}$ the court decisively held that the FLSA could never support a pure gap time claim both because a relevant 1987 DOL Letter Ruling recognized overtime gap time but not pure gap time, and because the statutory text does not facially compel reimbursement for pure gap time. ${ }^{141}$ As to overtime gap time, the court undertook no such analysis and made no such proclamation. ${ }^{142}$

Of course, a similar textual analysis could have foreclosed the overtime gap time claim: $\S 206$ does not address unpaid straight time even if the employee works the unpaid straight time hours during overtime weeks. ${ }^{143}$ In fact, as discussed below, other courts employed this precise reasoning and have rejected overtime gap time claims purely because the minimum wage and overtime provisions do not explicitly provide for such claims. ${ }^{144}$ The two-part analysis suggests the court did not find overtime gap time per se legally impermissible.

Similarly, the factual inquiry that compelled the court to dismiss the overtime gap time claims equally compelled it to dismiss the pure gap time claims. Because the employee's salaries compensated them for all hours up to the overtime threshold, the employees could not conceivably have

\footnotetext{
137. See id. at $1273-84$.

138. See id.

139. Id. at 1266.

140. The case could have been decided entirely on the facts. The court held that the officers received proper compensation for all nonovertime hours. Id. at 1276 ("Plaintiffs contend in Claim 1 that because the County regularly scheduled them for 135 hours per cycle, instead of the 147 maximum allowed, their salary only compensated them for those 135 hours and that they are therefore due the gap compensation when overtime hours were worked. This argument seems counter-intuitive and rather absurd for several reasons."). Naturally then, no pure gap time hours even existed.

141. Id. at 1280, 1283-84 (finding that because $\S 206$ does not facially require reimbursement for unpaid straight time, "there can be no violation of the FLSA for failure to pay such pure gap time claims," where the officers worked more than 135 hours but less than 147 hours in the pay cycle).

142. See id.

143. See 29 U.S.C. $\$ 206$ (2012).

144. Lundy v. Catholic Health Sys. of Long Island Inc., 711 F.3d 106, 116 (2d Cir. 2013).
} 
proved pure gap time on the facts. Rather than truncating its inquiry and resolving the entire case on the facts, the Fourth Circuit undertook a distinct, lengthy legal analysis and instead categorically rejected all pure gap time claims. ${ }^{145}$

In summary, Monahan's language and reasoning illustrate that the Fourth Circuit recognizes a cause of action for overtime gap time. Several courts have since recognized Monahan's implicit holding. ${ }^{146}$ However, not all courts accept its reasoning. ${ }^{147}$

145. Monahan, 95 F.3d at 1280-84.

146. See, e.g., Davis v. Abington Mem'l Hosp., 765 F.3d 236, 244 (3d Cir. 2014) ("However, some courts have recognized as viable gap time claims by an employee who exceeds the overtime threshold, but whose employment contract does not compensate him or her for all non-overtime hours ('overtime gap time'). . . We need not resolve the issue in this case because ... plaintiffs have not plausibly alleged that they worked overtime." (citations omitted)); Lundy, 711 F.3d at 116 ([S]ome courts may allow such claims to a limited extent. Among them is the Fourth Circuit in Monahan (citations omitted)); Rosario v. First Student Mgmt. LLC, No. 15-6478, 2016 U.S. Dist. LEXIS 108172, at *12-13 (E.D. Pa. Aug. 15, 2016) ("Two courts have directly addressed this narrow issue of whether the FLSA contemplates overtime gap time claims: the Second Circuit in Lundy v. Catholic Health Sys. [sic] of Long Island Inc., 711 F.3d 106 (2d Cir. 2013) and the Fourth Circuit in Monahan v. Cnty. [sic] of Chesterfield, Va., 95 F.3d 1263 (4th Cir. 1996) The result was a circuit split with the Fourth Circuit recognizing the viability of overtime gap time claims in limited circumstances and the Second Circuit soundly rejecting overtime gap time claims under the FLSA."); Perez v. Wells Fargo \& Co., 75 F. Supp. 3d 1184, 1192 (N.D. Cal. 2014) (discussing Monahan and conceding that Donovan v. Crisostomo, 689 F.2d 869 (9th Cir. 1982), arguably provided basis for an overtime gap time claim in the Ninth Circuit, but ultimately finding that Donovan did not govern the issue before it because the plaintiffs in the present case asserted a pure gap time claim); Espenscheid v. DirectSat USA, LLC, No. 09-cv-625-bbc, 2011 U.S. Dist. LEXIS 154706, at *31 (W.D. Wis. Apr. 11, 2011) (“Although the majority of courts reject pure gap-time claims, many courts have recognized gap time claims if (1) an employee exceeds the overtime threshold; and (2) the employment contract does not expressly or implicitly compensate the employee for all non-overtime hours." (citing Monahan, 95 F.3d at 1272 73.)); Valcho v. Dall. Cty. Hosp. Dist., 658 F. Supp. 2d 802, 811 (N.D. Tex. 2009) (finding no Fifth Circuit controlling precedent, but stating that "courts generally recognize claims for unpaid straighttime pay when the employee has worked overtime qualifying hours during that pay period" and citing Monahan as an example of the majority approach); Koelker v. Mayor \& City Council, 599 F. Supp. 2d 624, 635 (D. Md. 2009) (finding that Monahan required it "to allow a straight time compensation claim 'for gap hours when overtime hours [are] worked during a pay cycle"); Barvinchak v. Ind. Reg'1 Med. Ctr., No. 3:2006-69, 2007 WL 2903911, at *5-6 (W.D. Pa. Sept. 28, 2007) ("[T] he court analyzed the pure gap time and overtime gap time claims separately." (citing Monahan, 95 F.3d at 1284)).

147. Rosario, 2016 U.S. Dist. LEXIS 108172, at*15-18 (noting that the Third Circuit had not resolved the issue, but finding Lundy persuasive); Espenscheid, 2011 U.S. Dist. LEXIS 154706, at *29, *31-38 (finding that though the Seventh Circuit has not yet considered the gap time issue, the FLSA's text does not specifically provide for overtime gap time, and the overtime context does not justify treating overtime and pure gap time differently); Hensley v. First Student Mgmt., No. 15-3811, 2016 U.S. Dist. LEXIS 43000, at *9-12 (D.N.J. Mar. 31, 2016) (recognizing that "[o]nly two Circuits have directly addressed this issue," and finding insufficient statutory basis in the FLSA's plain text for overtime gap time). 
3. Lundy v. Catholic Health System of Long Island Inc.

In Lundy v. Catholic Health System of Long Island Inc., the Second Circuit rejected Monahan and forbade both pure and overtime gap time claims under the FLSA. ${ }^{148}$ There, three healthcare professionals filed a class action lawsuit against their employer Catholic Health System of Long Island Inc. ("CHS"), a healthcare group. ${ }^{149}$ The employees alleged that CHS violated the FLSA when it used an automatic time-keeping system that failed to compensate them for work time spent at training sessions, during pre-shift preparation and post-shift closing duties, and for work the employees completed during the employees' scheduled lunch breaks. ${ }^{150}$ They sought remuneration for both pure and overtime gap time. ${ }^{151}$

The court rejected the employees' overtime and pure gap time claims with relatively little comment. ${ }^{152}$ It dismissed the pure gap time claim in a single sentence, merely noting, "[a]n employee who has not worked overtime has no claim under FLSA for hours worked below the 40-hour overtime threshold, unless the average hourly wage falls below the federal minimum wage." $" 153$

As to the overtime gap time claim, the Second Circuit primarily relied on the FLSA's text. ${ }^{154}$ Conceding that some courts recognize overtime gap time, the Second Circuit nonetheless deemed the textual support for overtime gap time insufficient. ${ }^{155}$ It reasoned that because the FLSA only governs minimum wages and overtime hours, its text in no way addresses overtime gap time. ${ }^{156}$ According to the Second Circuit, the minimum wage provision only provides a remedy if the employee receives an average hourly wage below the statutory minimum, and the overtime provision provides a remedy only if the employer does not properly compensate the employee for overtime hours. ${ }^{157}$ Thus, the court explained, the FLSA provides no recourse for uncompensated straight time hours unless the

\footnotetext{
148. Lundy, 711 F.3d at $115-16$.

149. Id. at 110

150. Id. at $110-11$.

151. See id. at 115-16.

152. See id. at 109, 115-17.

153. Id. at 115 .

154. See id. at 116-17.

155. Id. at 116.

156. Id.

157. Id.
} 
employer's pay practices independently violate the minimum wage provision. ${ }^{158}$

The court further declined to rely on the interpretive guidance set forth under $\S 778.315$ and $\S 778.317 .{ }^{159}$ Such guidance, it explained, merits deference only to the extent the court finds its thoroughness, reasoning, consistency with other pronouncements, and other characteristics persuasive. ${ }^{160}$ Calling the guidance "unreasoned," the court summarily concluded that because the interpretations lack sufficient independent statutory support, they are not persuasive. ${ }^{161}$ Finally, the Second Circuit noted that state labor and contract laws provide adequate legal protection. ${ }^{162}$ It turned to the plaintiff's other claims without additional comment. $^{163}$

\section{ANALYSIS}

The appropriate treatment of overtime gap time vexes even the brightest legal minds. ${ }^{164}$ Courts disagree about whether the overtime provision inherently supports a remedy for overtime gap time, ${ }^{165}$ the appropriate weight to afford the FLSA's intended purpose, ${ }^{166}$ and whether the Administrator's advisory interpretation merits deference. ${ }^{167}$

This Comment advocates for a pro-overtime gap time, "Monahan approach," and rejects the contrary "Lundy approach." It urges that the Monahan approach best resolves the overtime gap time problem because (a) the overtime provision implicitly requires a remedy for overtime gap time, (b) failure to recognize a remedy for overtime gap time would directly contravene the purpose of the overtime provision, and (c) the Administrator's guidance merits deference.

\section{A. The Overtime Provision Fills the Gap}

Though the FLSA does not explicitly address overtime gap time, its

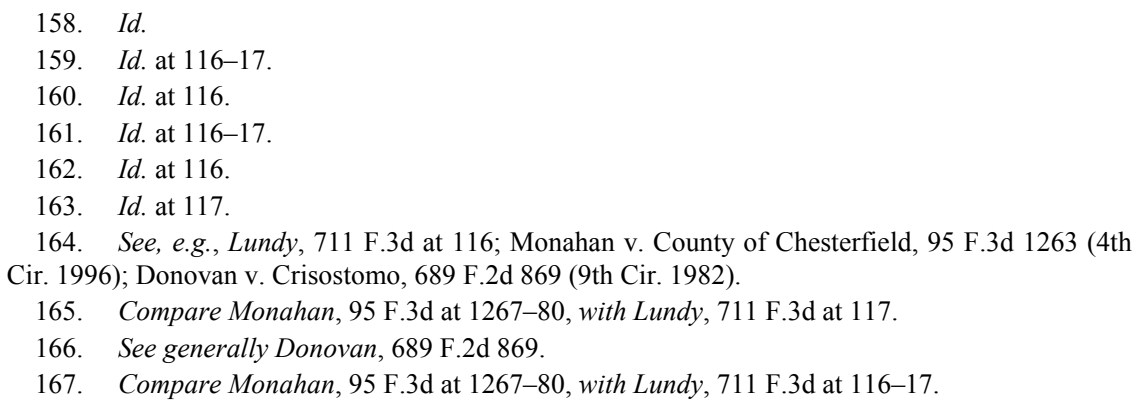


language and structure inherently require employers to compensate employees for every hour worked during overtime workweeks. ${ }^{168}$ This requirement derives from (1) the textually mandated "regular rate of pay" and its relationship to the overtime provision, and (2) the assumption, implicit in the overtime provision's use of the regular rate, that the employer has paid the employee for the hours he or she actually worked. ${ }^{169}$ The Monahan approach provides a reasoned solution to an ambiguous statutory question, while the Lundy approach confuses the term "regular rate of pay" and renders the statutory overtime premium ineffective.

First, the Monahan approach best reconciles (1) the definition of regular rate ("the hourly rate actually paid for the normal, non-overtime workweek" ${ }^{\prime 170}$ ), with (2) the formula for computing the regular rate (total remuneration / the total number of [nonovertime] ${ }^{171}$ hours actually worked in given workweek ${ }^{172}$ ), and (3) the formula for computing overtime compensation (one and one-half times the regular rate of pay ${ }^{173}$ ). In ambiguity, legal scholars often construe statutory text so as to make the text's terms operate consistently. ${ }^{174}$

Of course, because salaried employees may work different hours from week to week, their regular rates may fluctuate. However, the regular rate should not fluctuate when an employee is paid a specified sum for every hour of work, but should instead logically equal the employee's agreed upon wage multiplied by the number of hours worked. Critically, overtime gap time will never arise when an employee receives a weekly salary that compensates the employees for all hours worked up to the overtime threshold because in such circumstances, no straight time hours exist to slip between the statutory gap between the minimum wage and overtime provisions. Thus, any time overtime gap time arises, the term "regular rate" should operate consistently.

168. See Monahan, 95 F.3d at 1267-80; Donovan, 689 F.2d at 872-76.

169. See Barvinchak v. Ind. Reg'1 Med. Ctr., No. 3:2006-69, 2007 WL 2903911, at *5-6 (W.D. Pa. Sept. 28, 2007).

170. 149 Madison Ave. Corp. v. Asselta, 331 U.S. 199, 204 (1947) (quoting Walling v. Helmerich \& Payne, Inc., 323 U.S. 37, 40 (1944)), modified, 331 U.S. 795 (1947).

171. See 29 C.F.R. $§ 778.322$ (2017) (explaining the consequences of reducing the fixed workweek for which a salary is paid below forty hours).

172. 29 C.F.R. § 778.109 (2017); Bay Ridge Operating Co. v. Aaron, 334 U.S. 446, 461 (1948) ("Once the parties have decided upon the amount of wages and the mode of payment the determination of the regular rate becomes a matter of mathematical computation, the result of which is unaffected by any designation of a contrary 'regular rate' in the wage contracts." (quoting Walling v. Youngerman-Reynolds Hardware Co., 325 U.S. 419, 424-25 (1945))).

173. 29 U.S.C. $\S 207(\mathrm{a})(1)(2012)$.

174. Cass R. Sunstein, Justice Scalia's Democratic Formalism, 107 YALE L.J. 529, 535 (1997) (book review). 
Consider the hypothetical in the Introduction of this Comment. As defined, Ernst's regular rate of pay is $\$ 12$ per hour, and his employer owes him $\$ 570$ for 45 hours of work $((\$ 12 \times 40=\$ 480)+((1.5 \times \$ 12=\$ 18$ overtime premium rate) x $5=\$ 90)=\$ 570)$. However, because his employer only paid him $\$ 420$ total ( $\$ 12$ per hour x 35 hours paid), as computed, his regular rate is $\$ 9.33$ ( $\$ 420 / 45$ hours actually worked $=$ \$9.33). Similarly, in the hypothetical Weeks 1-4 described in Part II.a. of this Comment, Ernst's mathematical regular rate fluctuates from week to week: it is $\$ 11.40$ in Week 1, impermissibly dips below the minimum wage to $\$ 6.00$ in Week 2, rises to $\$ 11.43$ again in Week 3, and falls again to $\$ 10.86$ in Week 4. Because the slaughterhouse failed to properly compensate Ernst for all hours worked, his regular rate becomes " "irregular' in a mathematical sense." 175

Under these circumstances, it is also unclear whether the slaughterhouse should reimburse Ernst in an amount necessary to elevate his overtime rate to an amount equal to one and one-half times the rate the parties agreed Ernst would receive for each nonovertime hour, or an amount equal to the mathematical regular rate of pay. For example, in the opening hypothetical a court could reasonably conclude that Ernst's regular rate is $\$ 9.33$, and compute an accompanying overtime rate of $\$ 14$ rather than $\$ 18$. Under this hypothetical, Ernst would receive a diminished overtime rate of pay. Thus, the Lundy standard diminishes the de facto regular rate to amounts below the intended regular rate, and ultimately the formula for computing the regular rate conflicts with its definition and relationship to the overtime premium.

In contrast, if the slaughterhouse paid Ernst overtime gap time, his regular rate would be just as intended-regular. The slaughterhouse would be compelled to reimburse Ernst for the unpaid straight time hours: every overtime week his regular rate would equal $\$ 12$, and his overtime rate would equal $\$ 18$. The Monahan approach appropriately relieves courts from the burden of discerning the appropriate method of determining the regular rate for overtime purposes because it ensures the definition of regular rate and the formula for computing it align.

The Lundy approach also creates ambiguity concerning the amount of overtime compensation an employer owes his employees for unpaid overtime hours during workweeks with gap time and leaves courts with a choice between two competing methods of computing back overtime compensation in workweeks with gap hours, each of which proves problematic. Specifically, the Lundy approach causes confusion as to whether: (1) the employer is entitled to assume the employee was paid his

175. Walling v. A. H. Belo Corp., 316 U.S. 624, 632 (1942). 
regular rate for the unpaid overtime hours such that he is only owed the difference between the regular rate and the overtime premium rate of pay (one and one-half times the regular rate), or (2) the employer must instead assume the employee worked but was not paid at all for the shorted hours (and was not even paid his regular rate for those hours), and must therefore pay the entire overtime premium.

Under the first, "mathematical method," an employer assumes the employee has accepted a reduced wage for all hours, distributes the amount it actually paid the employee evenly across all hours the employee actually worked (including the unpaid overtime hours), and accordingly may reduce the overtime premium he owes for each hour by the regular rate. Ultimately the employer will only owe an additional amount equal to one-half times the employees' regular rate of pay for all overtime hours. This is the approach the Second Circuit employed in Lundy. There, the court assumed that the employees impliedly agreed to accept a diminished regular rate of pay rate. ${ }^{176}$ So long as the employee receives one and onehalf times this diminished rate, the reduction in overtime pay is a logical result of the relationship between the regular rate of pay and the overtime provision.

The mathematical method avoids characterizing the unpaid straight time hours as ostensibly "paid" at a diminished rate for the purposes of computing reimbursement for those straight time hours while simultaneously characterizing unpaid overtime hours as "unpaid" for the purposes of computing overtime reimbursement. However, this interpretation conflicts with the method courts must use to compute the overtime premium for salaried employees under governing Supreme Court precedent. $^{177}$

In Missel, the Supreme Court expressly forbade employers from falsely attributing sums regularly paid to an employee via a weekly salary to the amount due for overtime hours at the heightened overtime premium. ${ }^{178}$ Under Missel, employers may not effectively avoid paying

176. Lundy v. Catholic Health Sys. of Long Island Inc., 711 F.3d 106, 116 (2d Cir. 2013) (citing United States v. Klinghoffer Bros. Realty Corp., 285 F.2d 487, 494 (2d Cir. 1960)).

177. See generally Overnight Motor Transp. Co. v. Missel, 316 U.S. 572 (1942), superseded by statute on other grounds, Portal-to-Portal Act of 1947, Pub. L. No. 80-49, \$10, 61 Stat. 84, 89 (codified as amended at 29 U.S.C. $\$ 260$ (2012) (finding that employers may not satisfy overtime pay obligations by attributing amounts paid for nonovertime work to overtime hours).

178. Id. at 581-83. In Missel, a transportation company paid its employees via a weekly salary, and argued the salary compensated them for all overtime and nonovertime hours, so that the "regular rate" fluctuated from week to week, and it only owed additional overtime compensation if the mathematical average reduced the overtime premium to a sum below one and one-half times the minimum wage. $I d$. 
all overtime compensation by characterizing unpaid overtime hours as ostensibly paid by a weekly salary, and under ordinary circumstances, ${ }^{179}$ may not compute the overtime premium based on one and one-half times a fluctuating, implicitly reduced regular rate of pay. ${ }^{180}$ Permitting employers to characterize the overtime hours as ostensibly paid effectively requires courts to characterize unpaid overtime hours as supplemented by nonovertime compensation, which contravenes the Supreme Court's purpose and reasoning in Missel.

The second, "factual method" for computing overtime compensation allows courts to avoid falsely attributing amounts paid for nonovertime compensation to overtime work. Under the factual method, an employer owes the full overtime premium for all unpaid overtime hours but owes nothing for the unpaid straight time hours. The factual method is viable if one accepts that the employer failed to pay any overtime compensation as a factual matter. Of course, calling either method "factual" is necessarily a misnomer - characterizing any hours, even straight time hours, in which the employee in fact received zero dollars per hour requires courts to ignore the fact of nonpayment, a characteristic inherent to any gap time claim.

However, the factual method poses a distinct problem: to determine that the gap hours did not cause a minimum wage violation, and to compute the regular rate of pay, courts must necessarily attribute the mathematical rate to each hour, including overtime hours. Accepting that the employer paid nothing for the overtime hours and requiring full overtime compensation illogically requires courts to compute the overtime premium in a way that simultaneously characterizes the same straight time hours as paid and unpaid, and simultaneously characterize certain shorted hours as paid, but other shorted hours as unpaid. Thus, the Monahan approach properly avoids confusing the overtime provision's use of the regular rate, and provides for straightforward interpretation and calculation of that amount.

Finally, the FLSA's text arguably compels an employer to compensate his employees for each hour worked in overtime workweeks because one might reasonably read the overtime provision to inherently assume proper payment for nonovertime hours. Specifically, the textual requirement that employees receive an amount one and one-half times their regular rates of pay for hours that exceed the overtime threshold presumes that the

179. The FLSA provides for a fluctuating workweek in certain rare circumstances. See 29 C.F.R. $\S 778.114$ (a) (2017). This comment assumes the employer and employee have not agreed to a fluctuating workweek.

180. Id. 
employees have received compensation for each individual hour in the week, including the hours the employee must have worked to elevate his workweek above the overtime threshold. An employer cannot have effectively paid an employee one and one-half times his regular rate of pay unless the employee has received his regular rate of pay for the relevant week. Thus, under this second reading, the overtime provision's text requires a remedy for unpaid overtime gap time. ${ }^{181}$

\section{B. The Monahan Approach Accommodates the Act's Purpose}

The FLSA inherently provides a remedy for overtime gap time because only the Monahan approach adequately accounts for the Act's purpose. In contrast, the Lundy approach is repugnant to the Act's purpose because it negates the financial loss that the overtime penalty attempts to inflict on employers, thereby insufficiently encouraging employers to hire new employees, and it fails to fairly compensate employees for the additional hardship associated with long hours and insufficient pay. ${ }^{182}$

The Lundy approach contravenes the overtime provision's purpose because it rewards employers both for imposing unforgiving hours and for failing to properly compensate their employees. When employers escape paying employees overtime gap time, the uncompensated hours undeniably reduce the overall compensation employers must pay employees during overtime weeks. ${ }^{183}$ Such an approach impermissibly empowers employers to effectively extract wages from employees' straight time hours and reallocate them to overtime compensation. This result compels employees to supplement the employer's overtime obligation with their own earnings, and effectively pay for the additional work hours.

Under the Lundy approach, the Act provides an effective loophole and gives employers an opportunity to circumvent the increased rate. ${ }^{184}$ Greedy employers might implement policies designed to exploit this failure, and as a result hire fewer employees and work each employee

\footnotetext{
181. The extent to which the term "regular rate of pay" also compels payment of overtime gap time is considered below. The regular rate is merely a tool that parties must use to determine the overtime rate of pay - it does not actually govern payment of nonovertime hours. However, as is explained below, the way that the regular rate operates becomes unclear in the context of overtime gap time, which makes the overtime rate of pay equally unclear. This poses a problem of consistency and is therefore considered in the consistency section. This subsection does not further discuss the term because the confusion arises with reference to its operation, not the statutory language.

182. See supra Part II.b.

183. 29 C.F.R. $\$ 778.109$ (2017).

184. See Donovan v. Crisostomo, 689 F.2d 869, 876 (9th Cir. 1982).
} 
additional hours. Though the Act treats straight time and overtime hours distinctly, employees' paychecks make no such distinction between the hours - whether the loss derives from overtime gap time or an unpaid overtime premium, the result is the same: decreased income. ${ }^{185}$ The mere fact that the FLSA compels employers to pay an overtime premium arguably makes this result untenable.

An example illustrates this absurdity. Recall Ernst. In the opening hypothetical, the slaughterhouse paid him $\$ 420$, rather than $\$ 570$ for fortyfive hours of work. Under the minimum wage calculation, we determined Ernst's mathematical rate of pay was $\$ 9.33$ per hour and that the slaughterhouse therefore did not violate $\S 206$. This sum is also his regular rate of pay under the formula for computing the regular rate $(\$ 420 / 45$ hours worked). Though Ernst's pay check does not delineate which sums were paid for which hours, and though the hourly allocation makes little difference to Ernst (who only sees the final sum), under the principles advanced by Lundy, courts might falsely assume he implicitly agreed to receive payment for all hours at a reduced rate and employ the mathematical method described above to reduce the amount of compensation owed to Ernst for the entirely unpaid overtime hours.

In fact, the slaughterhouse owes Ernst $\$ 90$ additional dollars for hours forty through forty-five $((\$ 12$ per hour x $1.5=\$ 18$ per hour $)$ x $5=\$ 90)$. However, courts that use the mathematical method would force the assumption (that Ernst received payment for all hours) used to compute back minimum wage compensation into the overtime context would instead submit that the slaughterhouse owes him $\$ 43.35$ for those hours (\$90 owed minus the amount he was initially paid for those hours under the wage rate calculation $(\$ 9.33$ per hour paid x $5=\$ 46.65)$; $(\$ 90-46.65$ $=\$ 43.35)$ ). This effectively diminishes both Ernst's overtime and overall compensation. In such case, even after the Department of Labor compels the employer to pay the back overtime hours, Ernst receives $\$ 463.35$ total ( $\$ 43.35$ owed $+\$ 420$ initially paid $=\$ 463.35$ total compensation), an amount that significantly undercuts the value of his overtime work and ensures Ernst ultimately receives an amount less than the $\$ 480$ the slaughterhouse would owe him even in a 40 hour nonovertime workweek.

The factual approach does not resolve this problem. Under that approach, courts assume the employer effectively paid the straight time hours at a diminished rate, but paid no compensation for the shorted

185. See 29 C.F.R. $§ 778.317$ (2017); cf. Espenscheid v. DirectSat USA, LLC, No. 09-cv-625bbc, 2011 U.S. Dist. LEXIS 154706, at *34-35 (W.D. Wis. Apr. 11, 2011) ("However, this is not quite accurate because an employer's failure to pay for nonovertime hours does not diminish an employee's overtime compensation. Rather, it diminishes the employee's overall compensation, but there is no language in the FLSA creating a cause of action for diminished overall compensation."). 
overtime hours. Ernst receives the full $\$ 90$ additional dollars for the overtime hours but receives nothing for the straight time hours, so that he ultimately receives $\$ 510$ ( $\$ 90$ owed $+\$ 420$ initially paid $=\$ 510$ total). Again, this sum undercuts the value of his overtime work- the employer ultimately pays Ernst an amount less than what it would have paid him if he had worked only two overtime hours $((\$ 18$ overtime rate $\times 2=\$ 36)+$ 480 due for the nonovertime hours $=\$ 516)$. Though this characterization does not facially violate the minimum wage provision because Ernst's mathematical average still exceeds the statutory minimum, the characterization effectively diverts wages from Ernst's nonovertime hours to falsely characterize his overtime hours as paid. Thus, under either the mathematical or factual approach, Ernst effectively supplements his employer's obligation.

The Lundy approach not only lends itself to exploitation, but also makes the Act's intended beneficiaries vulnerable to the precise exploitation the Act sought to ameliorate. The Act aimed to benefit very poor, working class Americans. ${ }^{186}$ Today, the WHD often defends nonEnglish speaking, poor, uneducated workers who lack bargaining power. Greedy employers take advantage of these vulnerabilities in ways that directly implicate overtime gap time: employers may purposely short employees' paychecks, fail to compensate them for pre-shift and post-shift work, fail to pay an overtime premium but demand long schedules. The FLSA should empower those seeking to enforce the law to require employers to reimburse employees for overtime gap. Allowing uncompensated work time to fall through the gap significantly erodes the purposes of the FLSA and places the burden of overtime compensation on the Act's targeted beneficiaries by requiring them to substitute their straight time hours for overtime compensation.

Of course, one might reasonably conclude that because the Act is silent concerning overtime gap time, courts should interpret it to provide no remedy for unpaid straight time hours during overtime weeks and instead allow the legislature to alter the Act's text if it chooses. ${ }^{187}$ Admittedly, courts and the Department of Labor plainly accept that the minimum wage provision does not provide a remedy for unpaid straight time during nonovertime weeks. ${ }^{188}$ Pursuant to this accepted treatment of straight time hours during nonovertime weeks, the result described above

186. LINDER, supra n. 81, at 9, 48 .

187. See ANTONin Scalia \& Bryan A. Garner, REAding LaW: The InTERPREtation of LEGAL TEXTS xii (2012).

188. See Monahan v. County of Chesterfield, 95 F.3d 1263, 1272-73 (4th Cir. 1996); 29 C.F.R. $\S 778.322$ (2017). 
is arguably not absurd at all, but merely a logical extension of the treatment of minimum wage hours during nonovertime weeks.

However, nothing in the Act facially compels courts to interpret the minimum wage provision to provide no remedy for pure gap time. One might rationally read the minimum wage provision to require payment for each individual hour worked. The minimum wage provision requires that employees receive "wages" at a "rate" of "7.25 an hour."189 It does not explain the "rate" "an hour" language, but these terms could certainly require employers to pay employees at least $\$ 7.25$ for each individual hour worked. Of course, failure to compensate hourly employees for even a single hour logically then violates the minimum wage provision because earning zero dollars in any single hour inherently involves working for less than the minimum wage in that hour. In fact, at least one circuit court has interpreted the minimum wage provision to require payment for all hours worked. ${ }^{190}$ Because common practice does not necessarily negate this natural reading, the Department of Labor's decision not to require courts to reimburse employees for pure gap time does not necessarily support an argument that the Act does not implicitly require employees to reimburse employees for unpaid hours.

Furthermore, the overtime context compels this disparate result both because the overtime provision facially ties its premium to a specified rate and because the overtime workweeks inherently differ from nonovertime weeks. Critically, the regular rate functions as the characteristic that divorces the overtime calculation from the more forgiving minimum wage "floor." 191 Unlike the overtime provision, the minimum wage provision does not compel adherence to an agreed rate of pay, but merely requires that employers pay employees at least a minimum amount. In contrast, the overtime provision's use of the regular rate of pay explicitly links employees' compensation to the rate at which they should have been paid, which requires their paychecks to be proportionately increased with each hour worked.

The overtime provision's purpose also justifies treating uncompensated straight time hours differently in overtime and nonovertime weeks. Though employees may not readily distinguish between overtime and nonovertime hours on their paychecks, they do readily distinguish between overtime and nonovertime weeks. The Act's structure and legislative history clearly illustrate that Congress appreciated

189. 29 U.S.C. $§ 206$ (2012).

190. Lamon v. City of Shawnee, 972 F.2d 1145, 1155-58 (10th Cir. 1992).

191. See Walling v. Helmerich \& Payne, Inc., 323 U.S. 37, 40-42 (1944). 
this intrinsic distinction; ${ }^{192}$ it treated the overtime penalty as a functional cap on the maximum workweek hours because it recognized that overtime workweeks are inherently more arduous. ${ }^{193}$

This difference compels courts to look more closely at the hours actually worked and actually paid in overtime weeks. Employees should receive an amount that truly reflects the additional strain they suffer in an overtime week. Under the Monahan approach, the unavailability of uncompensated pure gap time accords with the less significant remedy available under the minimum wage provision. Furthermore, providing full remuneration for overtime gap time adequately reflects the significant award associated with the overtime premium. Thus, the treatment pure and overtime gap time receive under the Monahan approach ultimately aligns with the workweeks to which they relate.

Proponents of the Lundy approach might reasonably determine that the courts need not construe the overtime provision to provide a remedy for overtime gap time because contract-based remedies and state-law overtime gap time claims provide employees with sufficient protection. Admittedly, several states compel employers to reimburse employees for unpaid straight time. ${ }^{194}$ However, not all states provide such a remedy, ${ }^{195}$ and logically, most employees (and especially low income employees who lack the financial stability to risk their livelihoods) would hesitate to sue their employers. Thus, both state and contractual remedies do not provide sufficient protection.

In sum, the Monahan approach best comports with the overtime provision's purpose because it penalizes employers who fail to hire new employees by requiring an overtime premium rate of pay, requires fair compensation for the additional suffering employees endure during overtime weeks, and logically distinguishes between pure and overtime gap time. Courts should not disregard facts and interpret the law in a way that contravenes its intent merely to better accommodate an employer's wrongdoing.

\footnotetext{
192. See 81 Cong. ReC. 7746 (1937) (letter of Sen. Hugo L. Black).

193. See LINDER, supra note 81 , at 40-42 (distinguishing a true maximum-hour provision from an overtime penalty).

194. See, e.g., IDAHO Code $§ 45-606$ (2006 \& Supp. 2013); Ky. Rev. Stat. ANN. § 337.020 (West 2011); N.Y. LAB. LAW § 663 (McKinney $2002 \& 2014$ Supp.); 43 Pa. STAT. AND CONS. STAT. ANN. § 333.104 (West 2009 \& 2014 Supp.); Lugo v. Farmers Pride, Inc., 967 A.2d 963, 970 (Pa. 2009).

195. See, e.g., KAN. STAT. ANN. § 44-1203 (2000 \& Supp. 2016).
} 


\section{The Administrator's Interpretation Merits Deference}

Finally, courts should recognize overtime gap time because several relevant, persuasive, and well-reasoned advisory interpretations explain that overtime compensation cannot have been properly paid unless all straight time compensation has been paid. ${ }^{196}$

Advisory interpretations do not carry the force of law, but instead merely indicate the construction that "the Administrator believes to be correct and which will guide him in the performance of his administrative duties under the Act." ${ }^{197}$ Advisory interpretations therefore do not bind courts. ${ }^{198}$ However, the Administrator of Labor promulgates opinions to faithfully execute his office, and does so "based upon more specialized experience and broader investigations and information than is likely to come to a judge in a particular case." 199 Thus, the interpretations provide significant guidance, ${ }^{200}$ and when ambiguity arises, judges routinely defer to the Administrator's expertise and accord the interpretations significant weight. $^{201}$

In Skidmore v. Swift \& Co., the Supreme Court cautioned that courts must determine administrative interpretations' persuasive force on a caseby-case basis, and in each case consider "the thoroughness evident in its consideration, the validity of its reasoning, its consistency with earlier and later pronouncements, and all those factors which give it power to persuade, if lacking power to control." ${ }^{202}$ The advisory regulations that require payment of overtime gap time are thoroughly considered, validly reasoned, and consistent with other pronouncements. ${ }^{203}$

First, the advisory opinions are thoroughly considered and based in sound reason. The Administrator does not simply summarily conclude that all straight time hours must be paid in overtime weeks, but explains that it rejects such an outcome because the incomplete pay structures have

\footnotetext{
196. 29 C.F.R. $§ 778.315$ (2017).

197. 29 C.F.R. $\$ 776.0 \mathrm{a}(\mathrm{a})(1)(2017)$.

198. Id. (explaining that the provisions only will guide the Administrator in his enforcement "unless and until he is otherwise directed by authoritative decisions of the courts").

199. Skidmore v. Swift \& Co., 323 U.S. 134, 139-40 (1944).

200. Id. at 140.

201. See, e.g., Udall v. Tallman, 380 U.S. 1, 16 (1965) ("When faced with a problem of statutory construction, this Court shows great deference to the interpretation given the statute by the officers or agency charged with its administration.”); Conzo v. City of New York, 667 F. Supp. 2d 279, 291 (S.D.N.Y. 2009) (finding it "appropriate to adhere to the [Department of Labor]'s interpretations").

202. Skidmore, 323 U.S. at 140.

203. See id.
} 
the "effect of diminishing the employee's total overtime compensation."204 The Administrator reasons that payments "ostensibly paid for overtime" cannot truly have been paid for overtime where certain of the employees' working hours remain unpaid in the same pay cycle. ${ }^{205}$

This reasoning is persuasive. Naturally, employers cannot freely allocate portions of a paycheck to specific working hours, skipping from one hour to the next as it suits the employer's financial interests. Though employers may allocate payments on paper, physical paychecks are not so readily separable. The Administrator correctly refused to divorce financial and administrative concepts from reality to better accommodate employers' failure to pay. ${ }^{206}$ Furthermore, employers necessarily incur overtime premiums for the last hours employees work during the week. Thus, permitting a pay structure that compensates employees for overtime but not gap time requires a true chronological gap between payments. The advisory opinions rationally caution against such an absurd result.

Finally, the relevant advisory opinions are certainly consistent with the other pronouncements, as is required under the Swift test. Sections 778.317 and 778.322 , which explain and illustrate section 778.315 , were issued more than thirty years ago. ${ }^{207}$ The WHD has not since wavered in its position. ${ }^{208}$ Furthermore, as explained above, the position is consistent with the overtime provision, construction of the term regular rate, and the purposes that Congress intended the overtime provision to serve. ${ }^{209}$

\section{CONCLUSIONS AND MOVING FORWARD}

The FLSA was enacted eighty years ago not to prescribe rigid rules, but to ensure downtrodden American workers received fair compensation for hard work, and to protect them from the dangers inherent to the new industrial workforce. Today, the Act's silence as to the appropriate treatment of overtime gap time threatens to undermine its meaning, operation, and purpose.

Ultimately, several sources provide a logical bridge between the minimum wage and overtime provisions and compel courts to recognize a

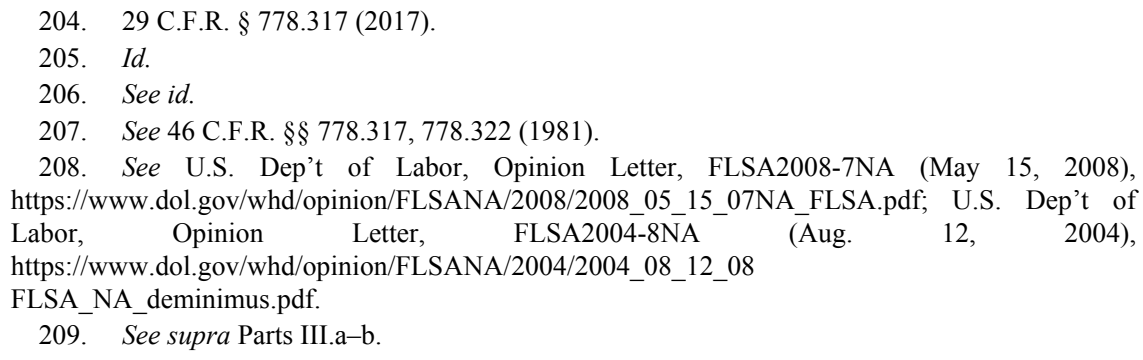


remedy for overtime gap time. The overtime provision's use of the "regular rate" and its operation logically require that employees receive all compensation due during overtime weeks. The intended premium overtime rate similarly compels this result. Failing to provide such a remedy for overtime gap time contravenes the Act's clear purpose. Finally, several Administrative Interpretations expressly compel payment of overtime gap time, and those interpretations are well reasoned and textually supported. In sum, the FLSA implicitly requires courts to recognize a remedy for unpaid overtime gap time. If courts attempt to leap the statutory gap between the Act's overtime and minimum wage provisions without considering these critical sources, they may very well find themselves in moral freefall. 